\title{
The release of calcium from the endoplasmic reticulum induced by amyloid-beta and prion peptides activates the mitochondrial apoptotic pathway
}

\author{
Elisabete Ferreiro, Catarina R. Oliveira, and Cláudia M.F. Pereira* \\ Center for Neuroscience and Cell Biology, Institute of Biochemistry, Faculty of Medicine, University of Coimbra, 3004-504 Coimbra, Portugal
}

Received 21 June 2007; revised 1 February 2008; accepted 6 February 2008

Available online 20 February 2008

In this study, we analyzed whether $\mathrm{ER} \mathrm{Ca}^{2+}$ release, induced by amyloid$\beta(A \beta)$ and prion (PrP) peptides activates the mitochondrial-mediated apoptotic pathway. In cortical neurons, addition of the synthetic $\mathrm{A} \boldsymbol{\beta} 1-40$ or PrP106-126 peptides depletes ER $\mathrm{Ca}^{2+}$ content, leading to cytosolic $\mathrm{Ca}^{2}$ ${ }^{+}$overload. The $\mathrm{Ca}^{2+}$ released through ryanodine (RyR) and inositol 1,4,5-trisphosphate $\left(I_{3} R\right)$ receptors was shown to be involved in the loss of mitochondrial membrane potential, Bax translocation to mitochondria and apoptotic death. Our data further demonstrate that $\mathrm{Ca}^{2+}$ released from the ER leads to the depletion of endogenous GSH levels and accumulation of reactive oxygen species, which were also involved in the depolarization of the mitochondrial membrane. These results illustrate that the early $\mathrm{A} \beta$ - and PrP-induced perturbation of $\mathrm{ER} \mathrm{Ca}^{2+}$ homeostasis affects mitochondrial function, activating the mitochondrial-mediated apoptotic pathway and help to clarify the mechanism implicated in neuronal death that occurs in AD and PrD.

(c) 2008 Elsevier Inc. All rights reserved.

Keywords: Alzheimer's disease; Prion disorders; Amyloid- $\beta$ peptide; Prion peptide; Apoptosis; $\mathrm{Ca}^{2+}$ homeostasis; Endoplasmic reticulum; Mitochondria; Oxidative stress

\section{Introduction}

Alzheimer's (AD) and Prion's diseases (PrD) are neurodegenerative disorders that share several common characteristics, including progressive dementia, accumulation of abnormally folded proteins and pronounced neuronal loss. AD and $\operatorname{PrD}$ appear to be caused, respectively, by the intracerebral accumulation of amyloid-

Abbreviations: A $\beta$, amyloid-beta peptide; PrP, prion peptide; $\mathrm{AD}$, Alzheimer's disease; APP, amyloid precursor protein; ER, endoplasmic reticulum; $\mathrm{IP}_{3} \mathrm{R}$, inositol 1,4,5-triphosphate receptor; $\Delta \psi_{\text {mit }}$, mitochondrial membrane potential; PrD, Prion disorders; PTP, mitochondrial transition pore; ROS, reactive oxygen species; RyR, ryanodine receptor.

* Corresponding author. Fax: +351 239822776.

E-mail address: cpereira@cnc.cj.uc.pt (C.M.F. Pereira).

Available online on ScienceDirect (www.sciencedirect.com). beta $(A \beta)$, resulting from the abnormal cleavage of the amyloid precursor protein (APP), or by the scrapie isoform of prion protein $\left(\mathrm{PrP}^{\mathrm{Sc}}\right)$, an abnormal isoform of the cellular form of the prion protein $\left(\mathrm{PrP}^{\mathrm{c}}\right)$ (Prusiner, 1996; Wisniewski et al., 1997).

Increasing evidence support that the endoplasmic reticulum (ER) stress-initiated cell death pathway is involved in $\mathrm{AD}$ and $\mathrm{PrD}$ (Katayama et al., 1999; Nakagawa et al., 2000; Hetz et al., 2003, 2005). The ER is an essential intracellular organelle involved in calcium homeostasis, and in the folding and processing of proteins (Baumann and Walz, 2001). In response to several stimuli that perturb the normal ER function, protein misfolding occurs and unfolded proteins accumulate in the ER (Kaufman, 1999; Pashen, 2001), activating the unfolded protein response (UPR). Under conditions of severe or prolonged ER dysfunction, UPR can trigger apoptotic cell death (Kaufman, 1999; Oyadomari et al., 2002).

$\mathrm{Ca}^{2+}$ release from the ER is mediated by ryanodine receptors (RyR) and inositol 1,4,5-trisphosphate receptors $\left(\mathrm{IP}_{3} \mathrm{R}\right)$ (Berridge et al., 2000). When large amounts of $\mathrm{Ca}^{2+}$ are released, mitochondria can capture a significant $\mathrm{Ca}^{2+}$ fraction due to the close physical proximity between the two organelles (Rizzuto et al., 1998; Csordas et al., 1999). The massive $\mathrm{Ca}^{2+}$ influx into mitochondria can collapse mitochondrial membrane potential $\left(\Delta \psi_{\text {mit }}\right)$ (Duchen, 2000; Hajnóczky et al., 2000). Loss of $\Delta \psi_{\text {mit }}$ can also result from the opening of the mitochondrial transition pore (PTP), resulting in the release of apoptogenic factors, including cytochrome $c$ (Kroemer et al., 1998). Once in the cytosol, cytochrome $c$ binds to the apoptosis-inducing factor (AIF) and activates caspase-9, which in turn activates caspase3 that cleaves several cellular substrates, culminating in cell death (Zoratti and Szabo, 1995; Liu et al., 1996; Li et al., 1997). Several proteins of the Bcl-2 family have been implicated in the mitochondria-mediated apoptosis (Kluck et al., 1997; Yang et al., 1997; Wei et al., 2001). The translocation of the pro-apoptotic protein Bax to the mitochondria, where it oligomerizes and forms a channel in the outer membrane, can promote the release of cytochrome $c$ (Wei et al., 2000; Cheng et al., 2001).

We have previously shown that A $\beta 1-40$ and PrP106-126 peptides trigger apoptosis due to the early release of $\mathrm{Ca}^{2+}$ from 
ER through the RyR and $\mathrm{IP}_{3} \mathrm{R}$ (Ferreiro et al., 2004, 2006). The aim of this study was to determine whether activation of the mitochondria-mediated apoptotic pathway is triggered by $A \beta 1-40$ and PrP106-126-induced $\mathrm{Ca}^{2+}$ release. Furthermore, generation of reactive oxygen species (ROS) will be examined as a possible link between $\mathrm{ER} \mathrm{Ca}^{2+}$ release and loss of mitochondrial function. The evidence gathered in this study indicates that A $\beta 1-40$ and PrP106126-induced $\mathrm{ER} \mathrm{Ca}^{2+}$ release affects mitochondrial function by a mechanism that involves the generation of ROS, possibly amplifying the ER stress-mediated apoptosis induced by these two peptides.

\section{Materials and methods}

\section{Materials}

Neurobasal medium and B27 supplement were purchased from Gibco BRL, Life Technologies (Scotland, UK). Trypsin, deoxyribonuclease I (DNase I), trypsin inhibitor type II-S-soybean, protease inhibitors, phenylmethylsulfonyl fluoride (PMSF), bovine serum albumin (BSA), dantrolene, xestospongin $\mathrm{C}$, reduced glutathione (GSH), o-Phthalaldehyde (OPT), rhodamine 123 (Rh123), D- $\alpha$ tocopherol succinate (vitamin E), Coenzyme $\mathrm{Q}_{10}$ (CoQ10), carbonyl cyanide 4-(trifluoromethoxy)phenylhydrazone (FCCP) and thapsigargin were obtained from Sigma Chemical Co. (St. Louis, MO, USA). SYTO-13, propidium iodide (PI) and Fura-2/AM were purchased from Molecular Probes (Leiden, Netherlands). The synthetic A $\beta 1-40$ peptide was from Bachem (Bubendorf, Switzerland) or American Peptides (Sunnyvale, CA, USA). PrP106-126 peptide was from Bachem (Bubendorf, Switzerland). Oligomycin and the Bax channel blocker (( \pm )-1-(3,6-Dibromocarbazol-9-yl)-3-piperazin-1-yl-propan-2-ol, bis TFA) were purchased from Calbiochem (Darmstadt, Germany). Bio-Rad protein dye assay, reagents and apparatus used in immunoblotting assays were purchased from BioRad (Hercules, CA, USA). Rabbit primary anti-bax antibody was from Cell Signalling (Danvers, MA, USA) and mouse primary anticytochrome $c$ antibody was from BD Pharmingen (San Diego, CA, USA). The goat anti-rabbit IgG conjugated to alkaline phosphatase, the enhanced chemifluorescence reagent (ECF) and the polyvinylidene difluoride (PVDF) membrane were obtained from Amersham Pharmacia Biotech (Buckinghamshire, UK). The fluorescent mounting medium was purchased from DakoCytomation (Carpinteria, California, USA). All the others chemicals were obtained from Sigma (St. Louis, MO, USA) or from Merck kgaA (Darmstadt, Germany).

\section{Primary cortical neuronal cultures and experimental treatments}

Primary cultures of cortical neurons were prepared from 15 to 16 days embryos of Wistar rats according to the method described by Hertz et al. (1989), with some modifications (Agostinho and Oliveira, 2003). Briefly, removed cortices were dissected and placed in $\mathrm{Ca}^{2+}$ and $\mathrm{Mg}^{2+}$-free Krebs buffer (in $\mathrm{mM}$ ): $\mathrm{NaCl} 120, \mathrm{KCl} 4.8, \mathrm{KH}_{2} \mathrm{PO}_{4}$ 1.2, glucose 13 and HEPES 10 (pH 7.4) supplemented with BSA $(0.3 \mathrm{mg} / \mathrm{mL})$. Minced cortical tissues were washed and incubated in Krebs solution supplemented with BSA, and containing trypsin $(0.5 \mathrm{mg} / \mathrm{mL})$ and DNase I $(0.04 \mathrm{mg} / \mathrm{mL})$, for $10 \mathrm{~min}$ at $37^{\circ} \mathrm{C}$. The digestion was stopped with Krebs buffer containing trypsin inhibitor (type II-S) $(0.75 \mathrm{mg} / \mathrm{mL})$ and DNase I $(0.04 \mathrm{mg} / \mathrm{mL})$, followed by a centrifugation at $140 \times g$ for $5 \mathrm{~min}$. After washing the pellet once with Krebs buffer, the cells were resuspended in fresh Neurobasal medium supplemented with $2 \mathrm{mM}$ L-glutamine, 2\% (v/v) B27 supplement, penicillin $(100 \mathrm{U} / \mathrm{mL})$ and streptomycin $(100 \mu \mathrm{g} / \mathrm{mL})$ and were dissociated mechanically. Cortical cells were plated on poly-L-lysine $(0.1 \mathrm{mg} / \mathrm{mL})$ coated glass coverslips at a density of $0.10 \times 10^{6}$ cells/ $\mathrm{cm}^{2}$ for single cell $\mathrm{Ca}^{2+}$ measurements, nuclear morphology studies using SYTO-13/PI and TUNEL assay. For the measurement of ROS levels and Rh123 retention, cells were plated on poly-L-lysine $(0.1 \mathrm{mg} / \mathrm{mL})$-coated dishes at a density of $0.10 \times 10^{6} \mathrm{cells} / \mathrm{cm}^{2}$. For immunoblotting, neurons were mounted on poly-L-lysine $(0.1 \mathrm{mg} /$ $\mathrm{mL}$ )-coated dishes at a density of $0.45 \times 10^{6}$ cells $/ \mathrm{cm}^{2}$. The cultures were maintained at $37^{\circ} \mathrm{C}$ in a humidified atmosphere of $5 \% \mathrm{CO}_{2} / 95 \%$ air and were used for experiments after 5 to 7 days in vitro. Under this culture conditions, $90 \%$ of the cells are neurons as evaluated using MAP-2 and GFAP immunoreactivity (Ferreiro et al., 2006). Differentiated cortical neurons were treated with $\mathrm{A} \beta 1-40(0.5 \mu \mathrm{M})$, PrP106-126 $(25 \mu \mathrm{M})$ or thapsigargin $(2.5 \mu \mathrm{M})$ in serum-free Neurobasal medium supplemented with B27. PrP106-126 was added from a stock solution prepared in sterile distilled water, at a concentration of $1 \mathrm{mM}$. A $\beta 1-40$ was dissolved in sterile distilled water, at a concentration of $6 \mathrm{mg} / \mathrm{mL}$ and diluted to $1 \mathrm{mg} / \mathrm{mL}(231.5 \mu \mathrm{M})$ with phosphate saline buffer (PBS) and then incubated for 5-7 days to induce fibril formation. Thapsigargin was added from a stock solution prepared in dimethylsulfoxide (DMSO), at a concentration of $5 \mathrm{mM}$. The concentrations of A $\beta 1-40, \operatorname{PrP} 106-126$ and thapsigargin used were chosen based on previous results demonstrating that, on cortical neurons, $0.5 \mu \mathrm{M}$ A $\beta 1-40,25 \mu \mathrm{M}$ PrP106-126 or $2.5 \mu \mathrm{M}$ thapsigargin induced a maximal toxic effect ( $50 \%$ decrease in cell viability). Before the addition of A $\beta 1-40$, PrP106-126 or thapsigargin, cells were preincubated for $1 \mathrm{~h}$ with dantrolene $(10 \mu \mathrm{M})$ or xestospongin $\mathrm{C}(1 \mu \mathrm{M})$ or pre-incubated for $20 \mathrm{~h}$ with vitamin $\mathrm{E}(13 \mu \mathrm{M})$ or CoQ10 $(1 \mu \mathrm{M})$. For nuclear morphology or Western blotting studies, using SYTO-13/PI, A $\beta 1-40$ - or PrP106-126-treated cells were pre-incubated 30 min with Bax blocker channel (25 or $50 \mathrm{nM})$.

Measurement of $\mathrm{ER}_{\mathrm{Ca}^{2+}}$ content

Measurement of ER $\mathrm{Ca}^{2+}$ content was assessed by single cell $\mathrm{Ca}^{2+}$ imaging, according to the method described by Nutt et al. (2002), with some modifications. Briefly, cells plated in coverslips were treated with $\mathrm{A} \beta 1-40(0.5 \mu \mathrm{M})$ or PrP106-126 $(25 \mu \mathrm{M})$ for 1 or $24 \mathrm{~h}$. Treated and control cells were washed 2 times in Krebs buffer (pH 7.4) (in mM: 132 $\mathrm{NaCl}, 4 \mathrm{KCl}, 1.4 \mathrm{MgCl}_{2}, 6$ Glucose, 10 HEPES, $10 \mathrm{NaHCO}_{3}, 1 \mathrm{CaCl}_{2}$ ) and loaded with Fura-2/AM $(5 \mu \mathrm{M})$ supplemented with $0.2 \%$ pluronic acid in Krebs buffer for $40 \mathrm{~min}$ at $37^{\circ} \mathrm{C}$, in the dark. Afterwards, cells were washed 3 times in $\mathrm{Ca}^{2+}$-free Krebs buffer, supplemented with $50 \mu \mathrm{M}$ EGTA, and the coverslip was assembled to perfusion chamber, with $500 \mu \mathrm{L}$ of $\mathrm{Ca}^{2+}$-free Krebs buffer, in an inverted fluorescence microscope Axiovert 200 (Zeiss, Germany). Cells were alternately excited at 340 and $380 \mathrm{~nm}$ using a Lambda DG4 apparatus (Sutter Instruments company, Nocato, CA, USA), and emitted fluorescence was collected with a $40 \times$ objective and was driven to a Coll SNAP digital camera (Roper Scientific, Trenton, NJ, USA). After a baseline was established, cells were stimulated with thapsigargin $(2.5 \mu \mathrm{M}$ final concentration), in the absence of extracellular $\mathrm{Ca}^{2+}$, to empty $\mathrm{Ca}^{2+}$ from ER. Acquired values were processed using the MetaFluor software (Universal Imaging Corporation, Buckinghamshire, UK). The peak amplitude of Fura-2 fluorescence (ratio at 340/380 nm) was used to evaluate $\mathrm{ER} \mathrm{Ca}^{2+}$ content.

\section{Western blotting analysis}

Mitochondrial and cytosolic extracts were prepared at $4{ }^{\circ} \mathrm{C}$ as followed: cells were washed with ice-cold PBS (all of the following 
procedures were performed at $4{ }^{\circ} \mathrm{C}$ ) and resuspended in a sucrose buffer containing (in mM): sucrose 250; HEPES-Na 20; $\mathrm{MgCl}_{2} 1.5$; $\mathrm{KCl}$ 10; EDTA 1; EGTA 1; DTT 1 and protease inhibitor cocktail (containing $1 \mu \mathrm{g} / \mathrm{mL}$ leupeptin, pepstatin $\mathrm{A}$, chymostatin and antipain). Lysates were homogenized and centrifuged at $1000 \times \mathrm{g}$ for $10 \mathrm{~min}$. The pellet corresponding to nuclei and unlysed cells was discarded and the supernatant was subjected to centrifugation at $10,000 \times \mathrm{g}$ for $30 \mathrm{~min}$. The pellet corresponding to the mitochondrial fraction was resuspended in lysis buffer. TCA $15 \%(\mathrm{v} / \mathrm{v})$ was added to the supernatant and centrifuged at $15,800 \times \mathrm{g}$ for $10 \mathrm{~min}$. The resulting pellet (cytosolic fraction) was resuspended in supplemented sucrose buffer and brought to $\mathrm{pH} 7$ with $\mathrm{NaOH}$. Protein concentration in the supernatant was measured using the Bio-Rad protein dye assay reagent. Samples were denaturated at $95{ }^{\circ} \mathrm{C}$ for 3 min in a $6 \times$ concentrated sample buffer $(\mathrm{mM})$ : Tris 500, DTT 600 , $10.3 \%$ SDS, $30 \%$ glycerol and $0.012 \%$ bromophenol blue. Equal protein amounts of each sample $(60 \mu \mathrm{g})$ were separated by electrophoresis on a 10\% SDS-polyacrylamide gels (SDS-PAGE) and electroblotted onto PVDF membranes. The identification of proteins of interest was facilitated by the usage of a prestained precision protein standard (Bio-Rad) which was run simultaneously. After the proteins were electrophoretically transferred, the membranes were incubated for $1 \mathrm{~h}$ at room temperature (RT) in Trisbuffer (mM): $\mathrm{NaCl} 150$, Tris- $\mathrm{HCl} 25$ (pH 7.6) with $0.1 \%$ Tween 20 (TBS-T) containing 5\% nonfat dry milk to eliminate nonspecific binding. Next, membranes were incubated overnight at $4{ }^{\circ} \mathrm{C}$ in TBS$\mathrm{T}$ containing $5 \%$ nonfat dry milk with a rabbit polyclonal primary antibody against $\operatorname{Bax}(1: 1000)$ or with mouse monoclonal primary antibody against cytochrome $c(1: 250)$. The membranes were washed several times and then incubated in TBS-T with $1 \%$ nonfat dry milk for $2 \mathrm{~h}$ at RT, with the alkaline phosphatase-conjugated with anti-rabbit secondary antibody at a dilution of 1:25,000. Immunoreactive bands were detected after incubation of membranes with ECF reagent for 5-10 min, on a Bio-Rad Versa Doc 3000 Imaging System (Bio-Rad, Hercules, CA, USA).

\section{Measurement of glutathione content}

Reduced glutathione (GSH) levels were determined with fluorescence detection, according to Moreira et al. (2005). In brief, cells were washed with ice-cold PBS, resuspended in perchloric acid $(0.6 \mathrm{M})$ and EDTA- $\mathrm{Na}^{+}(25 \mathrm{mM})$ and centrifuged at $15,800 \times \mathrm{g}$ for $2 \mathrm{~min}$ at $4{ }^{\circ} \mathrm{C}$. The pellet was resuspended in $\mathrm{NaOH}(1 \mathrm{M})$ and the protein concentration was measured using the Bio-Rad protein dye assay reagent. The supernatant $(100 \mu \mathrm{L})$ was added to $1.8 \mathrm{~mL}$ phosphate buffer and $100 \mu \mathrm{L}$ OPT. After mixing and incubation at RT for $15 \mathrm{~min}$, the solution was transferred to a quartz cuvette and the fluorescence was measured at 420 and $350 \mathrm{~nm}$ emission and excitation wavelength, respectively. The GSH content was calculated using a linear reduced GSH standard curve and the values expressed as the percentage above control.

\section{Measurement of intracellular reactive oxygen species}

ROS were measured according to Bass et al. (1983), by following the oxidation of $2^{\prime}, 7^{\prime}$-dichlorodihydrofluorescin $\left(\mathrm{DCFH}_{2}\right.$-DA) to fluorescent DCF. Plated cells, untreated or treated with A $\beta 1-40$, PrP106-126 or thapsigargin, in the presence or absence of CoQ10 or vitamin $\mathrm{E}$, were loaded with $5 \mu \mathrm{M} \mathrm{DCFH} \mathrm{DA}_{2}$ - $\mathrm{DA}$ in sodium medium containing: (in $\mathrm{mM}$ ): $\mathrm{NaCl} 132, \mathrm{KCl} 4, \mathrm{NaH}_{2} \mathrm{PO}_{4}$ 1.2, $\mathrm{MgCl}_{2}$ 1.4, glucose 6 , HEPES-Na $10, \mathrm{CaCl}_{2} 1, \mathrm{pH} 7.4$, for $20 \mathrm{~min}$ at $37^{\circ} \mathrm{C}$. After
$\mathrm{DCFH}_{2}$-DA incubation, cells were washed and sodium medium was added. DCF fluorescence signals, corresponding to intracellular ROS, was monitored for $30 \mathrm{~min}$ at $480 \mathrm{~nm}$ excitation and $550 \mathrm{~nm}$ emission (with a cutoff at $530 \mathrm{~nm}$ ), at $37^{\circ} \mathrm{C}$, using a temperature-controlled SpectraMax Gemini EM spectrometer (Molecular Devices, Sunnyvale, USA). The values were expressed as arbitrary units of the increase of DCF fluorescence above control values.

\section{Analysis of mitochondrial membrane potential}

The changes in mitochondrial membrane potential $\left(\psi_{\text {mit }}\right)$ were estimated using the fluorescent cationic dye Rh123, which accumulates in mitochondria as a direct function of the membrane potential and is released upon membrane depolarization (Palmeira et al., 1996, with some modifications). After exposure to A $\beta 1-40$, PrP106-126 or thapsigargin, in the presence or absence of CoQ10, vitamin $\mathrm{E}$, dantrolene or xestospongin $\mathrm{C}$, the cells were incubated
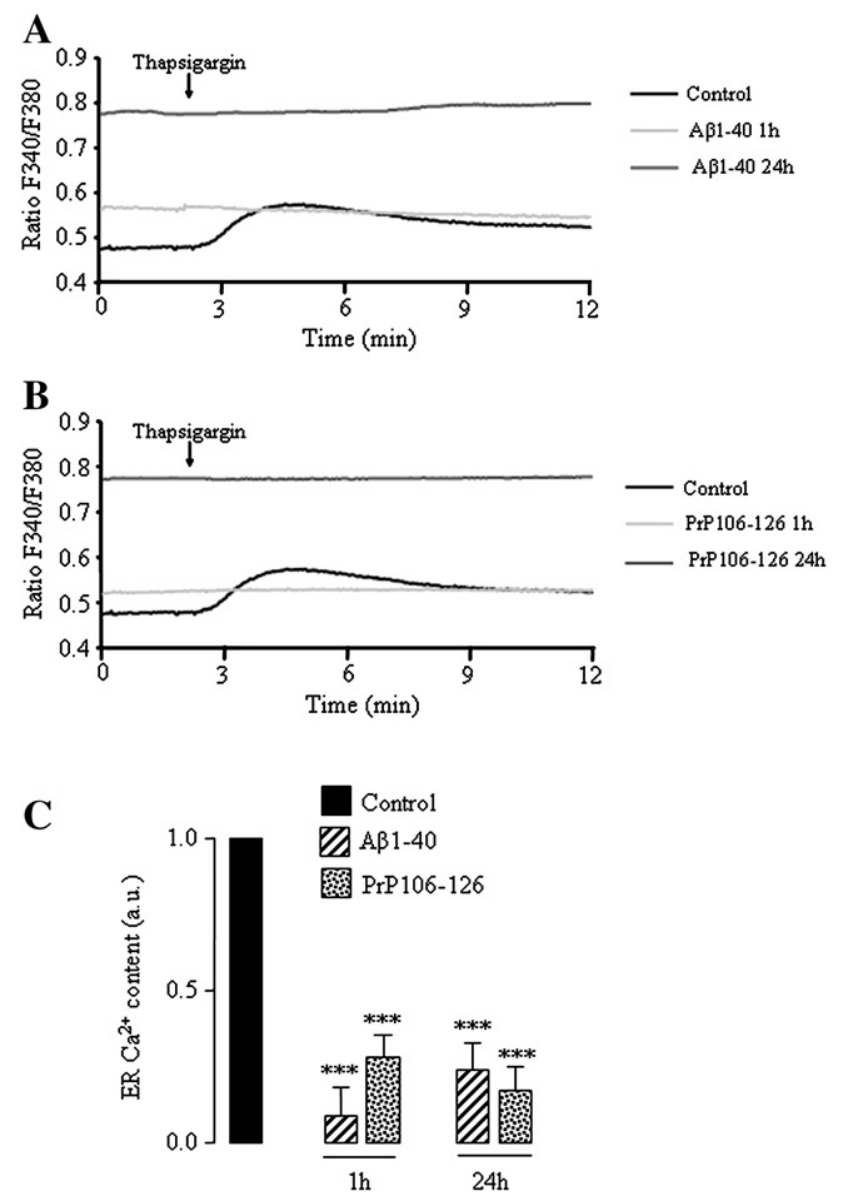

Fig. 1. A $1-40$ and PrP106-126 deplete ER $\mathrm{Ca}^{2+}$ content. The fluorescence ratio at $340 / 380 \mathrm{~nm}$ of the $\mathrm{Ca}^{2+}$-sensitive Fura-2/AM was monitored during $12 \mathrm{~min}$, in the absence of external $\mathrm{Ca}^{2+}$. After $2 \mathrm{~min}, 2.5 \mu \mathrm{M}$ thapsigargin was added to deplete $\mathrm{ER} \mathrm{Ca}^{2+}$. Representative F340/F380 traces of cortical neurons treated for 1 and $24 \mathrm{~h}$ with A $31-40(0.5 \mu \mathrm{M})(\mathrm{A})$ or with PrP106-126 $(25 \mu \mathrm{M})$ (B) are presented. The peak amplitude of Fura-2 fluorescence was used to evaluate $\mathrm{ER} \mathrm{Ca}^{2+}$ content and data from at least three different experiments, obtained from A 31 -40- or PrP106-126-treated neurons, were normalized to the values determined in untreated control cells $(C)$. Data were expressed as the mean \pm SEM. ${ }^{* * *} p<0.001$ with respect to control values. 
with Rh123 (1 $\mu \mathrm{M})$ in sodium medium containing: (in $\mathrm{mM}$ ): $\mathrm{NaCl}$ 132, $\mathrm{KCl} 4, \mathrm{NaH}_{2} \mathrm{PO}_{4} 1.2, \mathrm{MgCl}_{2}$ 1.4, glucose 6, HEPES-Na 10, $\mathrm{CaCl}_{2}$ 1, pH 7.4, for 45 min at $37^{\circ} \mathrm{C}$, in a SpectraMax Gemini EM spectrometer (Molecular Devices, Sunnyvale, USA). The fluorescence signals of the dye remaining trapped were monitored at $505 \mathrm{~nm}$ excitation and $525 \mathrm{~nm}$ emission. At the end of the $45 \mathrm{~min}$ incubation, FCCP $(1.5 \mu \mathrm{M})$ and oligomycin $(0.25 \mu \mathrm{g} / \mathrm{mL})$ were added in order to establish the maximum retention of Rh123. The difference between the fluorescence monitored before and after the addition of FCCP and oligomycin was used to evaluate the $\psi_{\text {mit }}$. The results were expressed as percentage of increase or decrease above control fluorescence.

\section{Assessment of neuronal injury}

After exposure of cortical cells to A $\beta 1-40(0.5 \mu \mathrm{M})$ or PrP106$126(25 \mu \mathrm{M})$, in the absence or in the presence of a Bax channel blocker ( 25 or $50 \mathrm{nM}$ ), neuronal injury was assessed as described in Ferreiro et al. (2004) using the fluorescent probes SYTO-13/PI. Control and treated neurons were incubated with SYTO-13 $(3.8 \mu \mathrm{M})$ and PI $(2.5 \mu \mathrm{g} / \mathrm{mL})$ and the nuclear morphology was analyzed using an Axiovert 200 fluorescence microscope (Zeiss, Germany). All experiments were performed in duplicate, and a minimum of 300 cells were scored for each coverslip. The number of apoptotic cells was expressed as the percentage (\%) of the total number of cells in the microscope field. Cell death was also analyzed by TUNEL staining, performed using an in Situ Cell Death Detection Kit, Fluorescein (Roche Applied Science, Mannheim, Germany) according to the manufacturer's directions. Cells were washed in PBS buffer ( $\mathrm{pH} 7.4)$ and were fixed with $4 \%$ paraformaldehyde for $30 \mathrm{~min}$ at RT. The slides were then immersed in $0.1 \%$ Triton X-100, supplemented with $0.1 \%$ sodium citrate in PBS, for $2 \mathrm{~min}$, on ice, to permeabilized the cells. After washing, slides were incubated in a mixture of the enzymatic solution with the label solution, for $1 \mathrm{~h}$ at $37^{\circ} \mathrm{C}$, in the dark. Finally, slides were washed with PBS and prepared with DakoCytomation Fluorescent mounting solution on a microscope slide for the visualization in an Axiovert Microscope 200 (Zeiss, Thornwood, NY, USA). DNAse pretreated cells were used as a positive control. The photographs were taken at a magnification of $400 \times$. Total number and positive-TUNEL cells were scored in the microscope field, 3 fields for each coverslips. The results were presented as the percentage (\%) of the total number of cells.

\section{Statistical analysis}

Results are expressed as means $\pm \mathrm{SEM}$ of the number of experiments indicated in the figure captions. Statistical significance was performed using an analysis of variance (ANOVA), followed by
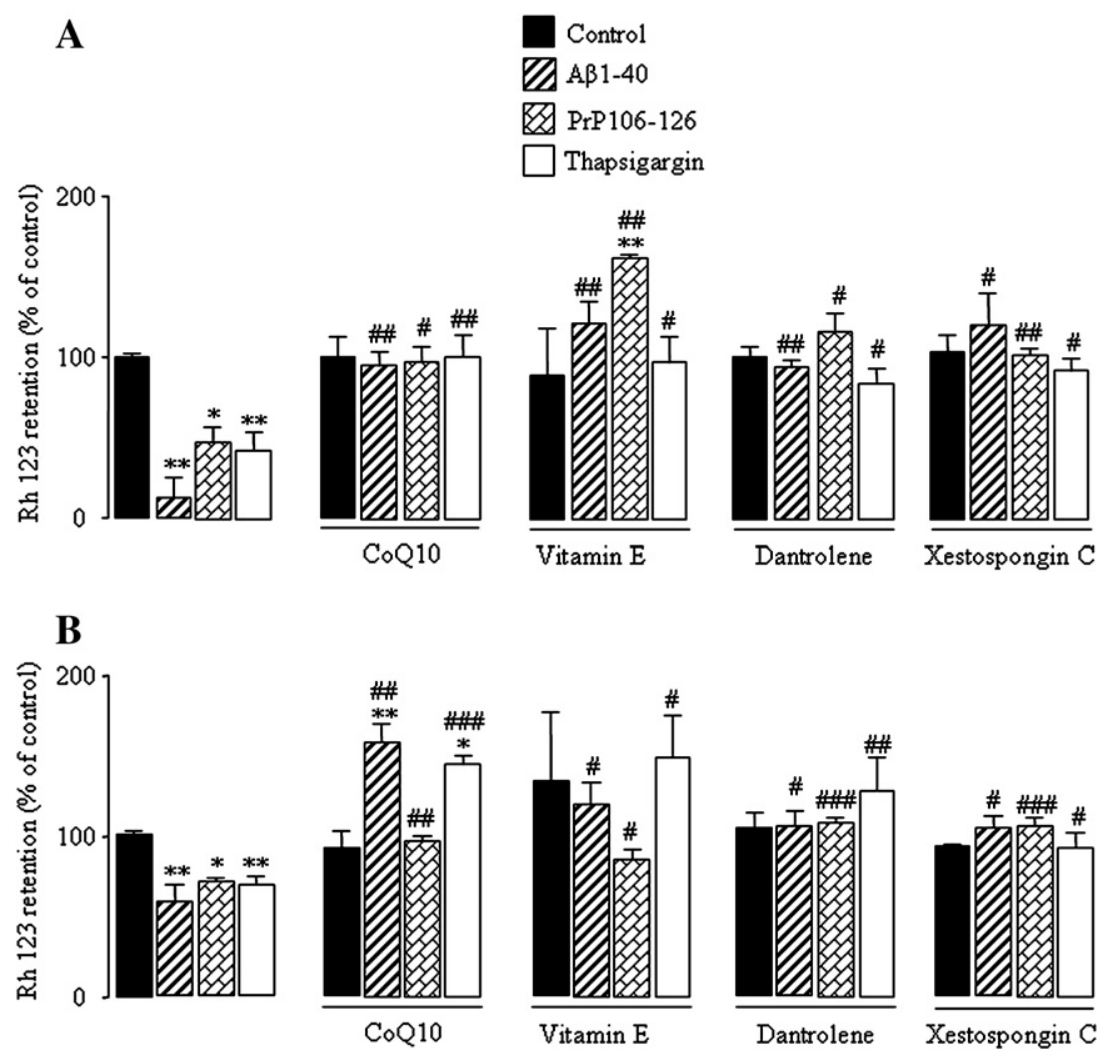

Fig. 2. A $\beta 1-40$ and PrP106-126 reduce $\Delta \Psi_{\text {mit }}$ Protection by antioxidants, $\mathrm{IP}_{3} \mathrm{R}$ and RyR inhibitors. Mitochondrial membrane potential $\left(\Delta \Psi_{\text {mit }}\right)$ was evaluated by the capacity of mitochondria from cortical neurons to take up the fluorescent cationic dye Rh123. Cells were incubated with A $\beta 1-40$ ( $0.5 \mu \mathrm{M})$, PrP106-126 $(25 \mu \mathrm{M})$ or thapsigargin $(2.5 \mu \mathrm{M})$, in the absence or in the presence of CoQ10 $(1 \mu \mathrm{M})$, vitamin $\mathrm{E}(13 \mu \mathrm{M})$, dantrolene $(10 \mu \mathrm{M})$ or xestospongin $\mathrm{C}(1 \mu \mathrm{M})$, for 6 (A) or $24 \mathrm{~h}$ (B). The results, expressed as the percentage of the baseline membrane potential of control cortical neurons, are the means \pm SEM of values corresponding at least to 3 experiments, each value being the mean of duplicate assays. ${ }^{*} p<0.05 ;{ }^{*} p<0.01$ with respect to control values. ${ }^{\#} p<0.05$; ${ }^{\# \#} p<0.01$; \#\#\# $p$ 0.001 with respect to $\mathrm{A} \beta, \operatorname{PrP}$ or thapsigargin addition. 
Dunnett's post-hoc tests for multiple comparisons or by the unpaired two-tailed Student's $t$-test. A $p<0.05$ value was considered statistically significant.

\section{Results}

AB1-40 and PrP106-126 deplete ER $\mathrm{Ca}^{2+}$ content

Several studies link ER stress and apoptosis to the perturbation of $\mathrm{ER} \mathrm{Ca}^{2+}$ homeostasis (Ferri and Kroemer, 2000). We have previously shown that the synthetic $\mathrm{A} \beta 1-40$ and PrP106-126 peptides significantly increase in cytosolic $\mathrm{Ca}^{2+}$ levels that was prevented in the presence of dantrolene and xestospongin $\mathrm{C}$, which inhibit the release of $\mathrm{Ca}^{2+}$ from the ER through the channels associated with RyR and $\mathrm{IP}_{3} \mathrm{R}$, respectively (Ferreiro et al., 2006) In order to further investigate whether ER $\mathrm{Ca}^{2+}$ levels are altered by both peptides, ER $\mathrm{Ca}^{2+}$ content was analysed by single cell $\mathrm{Ca}^{2+}$ imaging in $\mathrm{A} \beta 1-40-$ and PrP106-126-treated cortical neurons. Control cells and cells treated with A $\beta 1-40(0.5 \mu \mathrm{M})$ or PrP106-126 $(25 \mu \mathrm{M})$ for 1 or $24 \mathrm{~h}$, were loaded with the $\mathrm{Ca}^{2+}$ sensitive fluorescent dye Fura-2/AM. ER $\mathrm{Ca}^{2+}$ content was evaluated indirectly measuring Fura-2 fluorescence in the absence of external $\mathrm{Ca}^{2+}$, before and after the addition of thapsigargin, a SERCA-Ca ${ }^{2+}$ ATPase inhibitor, which depletes ER stores. Representative traces of Fura-2 fluorescence ratio at 340 and $380 \mathrm{~nm}$ are presented in Figs. 1A and B. Basal values of Fura-2 fluorescence ratio, measured before thapsigargin addition, were increased in $\mathrm{A} \beta$ - or PrP-treated neurons, when compared to the control (Figs. $1 \mathrm{~A}$ and $\mathrm{B}$ ), demonstrating that cytosolic $\mathrm{Ca}^{2+}$ levels are altered by both peptides (Figs. 1A and B), accordingly with our previous published results (Ferreiro et al., 2006).

To analyze the $\mathrm{ER} \mathrm{Ca}^{2+}$ content of neurons treated with $\mathrm{A} \beta$ or PrP peptides, peaks over baseline, obtained upon thapsigargin treatment, were calculated and the results normalized to ER $\mathrm{Ca}^{2+}$ content of untreated cortical neurons (Fig. 1C). After $1 \mathrm{~h}$ incubation, A $\beta 1-40$ $(0.5 \mu \mathrm{M})$ induced a significant decrease in neuronal ER $\mathrm{Ca}^{2+}$ content, which persisted at $24 \mathrm{~h}$. Similar results were obtained in cortical neurons treated with PrP106-126 $(25 \mu \mathrm{M})$ for 1 or $24 \mathrm{~h}$

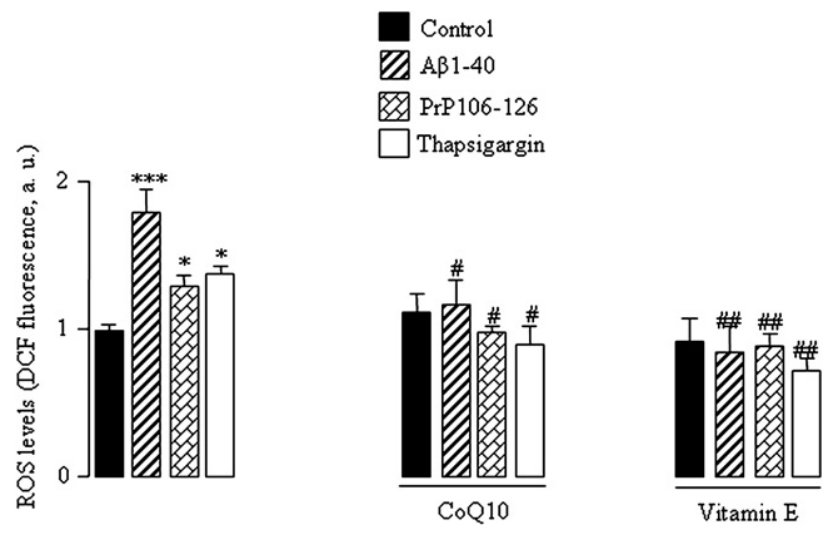

Fig. 3. A $\beta 1-40$ and PrP106-126 increase the intracellular reactive oxygen species (ROS) levels. Protection by CoQ10 and vitamin E. Cortical neurons were treated with $\mathrm{A} \beta 1-40(0.5 \mu \mathrm{M})$, PrP106-126 $(25 \mu \mathrm{M})$ or thapsigargin $(2.5 \mu \mathrm{M})$ for $6 \mathrm{~h}$, in the absence or in the presence of CoQ10 $(1 \mu \mathrm{M})$ or vitamin $\mathrm{E}(13 \mu \mathrm{M})$. Intracellular ROS levels were determined using the $\mathrm{DCFH}_{2}$-DA fluorescent probe. The results are the means \pm SEM of values corresponding at least 3 experiments, each value being the mean of duplicate assays. ${ }^{*} p<0.05 ;{ }^{* * *} p<0.001$ with respect to control values. ${ }^{*} p<0.05$; ${ }^{\# \#} p<0.01$ with respect to $\mathrm{A} \beta, \operatorname{PrP}$ or thapsigargin addition.
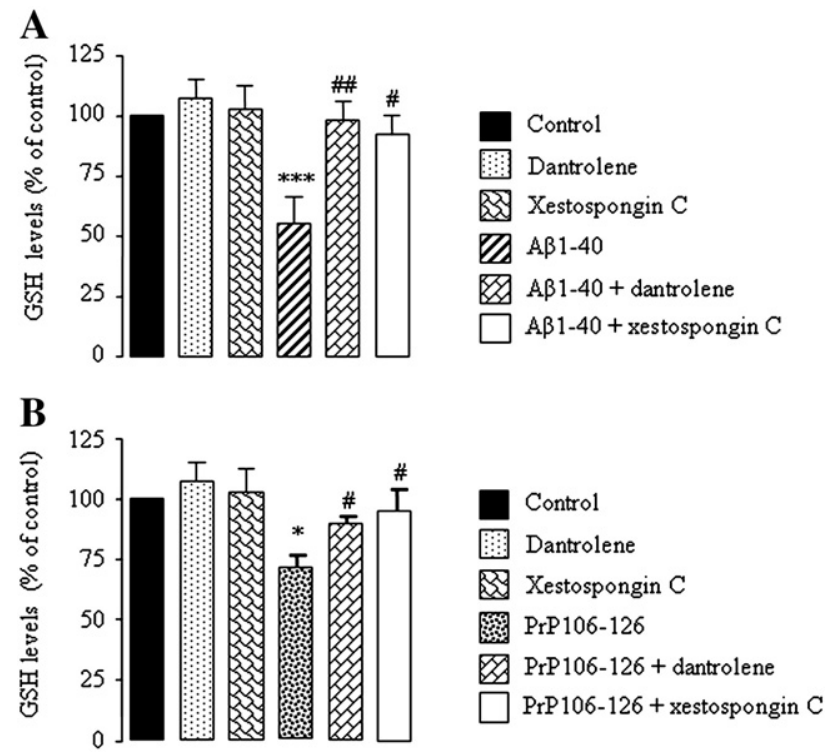

Fig. 4. GSH levels are increased in neurons treated with $A \beta 1-40$ or PrP106-126. Protection by dantrolene and xestospongin. Cortical neurons were treated for $24 \mathrm{~h}$ with $\mathrm{A} \beta 1-40(0.5 \mu \mathrm{M})(\mathrm{A})$ or PrP106-126 $(25 \mu \mathrm{M})$ (B), in the absence or in the presence of dantrolene $(10 \mu \mathrm{M})$ or xestospongin $\mathrm{C}(1 \mu \mathrm{M})$. GSH content, expressed as percentage of control values, are the means \pm SEM of values corresponding at least to 3 experiments, each value being the mean of duplicate assays. ${ }^{*} p<0.05$; $* * * p<0.001$ with respect to control values. ${ }^{\#} p<0.05 ;{ }^{\# \#} p<0.01$ with respect to $\mathrm{A} \beta$ or $\mathrm{PrP}$ addition.

$(p<0.001)$ (Fig. 1C). These results show that $\mathrm{A} \beta$ and PrP peptides affect $\mathrm{ER} \mathrm{Ca}^{2+}$ homeostasis in cortical neurons, inducing a substantial reduction in $\mathrm{ER} \mathrm{Ca}^{2+}$ content, which subsequently leads to the increase of cytosolic $\mathrm{Ca}^{2+}$ levels.

AB1-40 and PrP106-126 reduce $\Delta \Psi_{\text {mit }}$ and increase ROS levels. Protection by antioxidants, $I P_{3} R$ and RyR inhibitors

Increased intracellular free $\mathrm{Ca}^{2+}$ overload can lead to the excessive mitochondrial $\mathrm{Ca}^{2+}$ uptake, reduce the mitochondrial membrane potential $\left(\Delta \psi_{\text {mit }}\right)$ and disrupt electron transport, resulting in an increased production of the reactive free radical superoxide anion in neurons (Luetjens et al., 2000).

The changes in $\Delta \psi_{\text {mit }}$ induced by $\mathrm{A} \beta 1-40$ and PrP106-126 peptides were measured using the fluorescent cationic dye Rh123, which is known to be selectively taken up by mitochondria and reflect the maintenance of the mitochondrial membrane potential. To evaluate the involvement of ER $\mathrm{Ca}^{2+}$ release in the perturbation of $\Delta \psi_{\text {mit }}$, cortical neurons were pre-incubated with dantrolene, an inhibitor of RyR, or xestospongin $C$, an inhibitor of $\mathrm{IP}_{3} \mathrm{R}$, before the addition of A $\beta 1-40$ and PrP106-126 peptides. Furthermore, results obtained upon $\mathrm{A} \beta$ or PrP exposure were compared with that obtained in cells with thapsigargin, a known ER stress inducer, in the absence or in the presence of dantrolene or xestopongin $\mathrm{C}$. In addition, the effect of two well-known antioxidants, CoQ10 and vitamin E, was tested to evaluate whether reactive oxygen species (ROS) production upon $\mathrm{ER} \mathrm{Ca}^{2+}$ release perturbs the $\Delta \psi_{\text {mit }}$. As shown in Figs. $2 \mathrm{~A}$ and $\mathrm{B}$, treatment of cortical neurons with A $\beta 1-40(0.5 \mu \mathrm{M})$, PrP106$126(25 \mu \mathrm{M})$, or thapsigargin $(2.5 \mu \mathrm{M})$, leads to a significant drop of Rh123 retention, both at 6 (Fig. 2A) and 24 h (Fig. 2B). Furthermore, 
we can also depict that dantrolene $(10 \mu \mathrm{M})$ and xestospongin $\mathrm{C}$ $(1 \mu \mathrm{M})$ protected cells against A $\beta 1-40-$, PrP106-126- and thapsigargin-induced decrease of $\Delta \psi_{\text {mit }}$, since no alteration of Rh123 was observed under these conditions, demonstrating the involvement of $\mathrm{ER} \mathrm{Ca}^{2+}$ release in the perturbation of the $\Delta \psi_{\text {mit }}$. In addition, CoQ10 $(1 \mu \mathrm{M})$ and vitamin $\mathrm{E}(13 \mu \mathrm{M})$ also afforded protection against these toxic elements, revealing that ROS are involved in the altered $\Delta \psi_{\text {mit }}$ in response to A $\beta 1-40$, PrP106-126 or thapsigargin. CoQ10, vitamin $\mathrm{E}$, dantrolene or xestospongin $\mathrm{c}$ alone did not alter the $\Delta \psi_{\text {mit }}$ (Figs. 2A and B).

We have previously demonstrated that ${\mathrm{ER} \mathrm{Ca}^{2+}}^{2+}$ release is involved in ROS production induced by $\mathrm{A} \beta 1-40$ and PrP106-126 (Ferreiro et al., 2006). Here we tested the effect of CoQ10 and vitamin $E$ on $A \beta-$ or PrP-induced ROS generation. Once again, thapsigargin was used as a positive control. In cortical neurons treated for $6 \mathrm{~h}$ with $\mathrm{A} \beta 1-40$
(0.5 $\mu \mathrm{M}), \operatorname{PrP} 106-126(25 \mu \mathrm{M})$, or thapsigargin $(2.5 \mu \mathrm{M})$ a significant increase in cytosolic ROS levels was observed, which was completely suppressed by CoQ10 and vitamin E (Fig. 3). These results confirm that the effect of CoQ10 and vitamin $\mathrm{E}$ on the loss of $\Delta \psi_{\text {mit }}$ upon exposure to A $\beta 1-40$, PrP106-126 or thapsigargin is correlated with the suppression of ROS production.

Aß1-40 and PrP106-126 reduce GSH levels mediated by ER $\mathrm{Ca}^{2+}$ release

Reduction of $\Delta \psi_{\text {mit }}$ has been linked to depletion of reduced glutathione (GSH) (Macho et al., 1997), the most abundant antioxidant in the cell. A $\beta 1-40(0.5 \mu \mathrm{M})$ or PrP106-126 $(25 \mu \mathrm{M})$ induced a significant reduction of GSH levels in cortical neurons, after $24 \mathrm{~h}$ treatment (Figs. 4A and B). Furthermore, when cells were treated
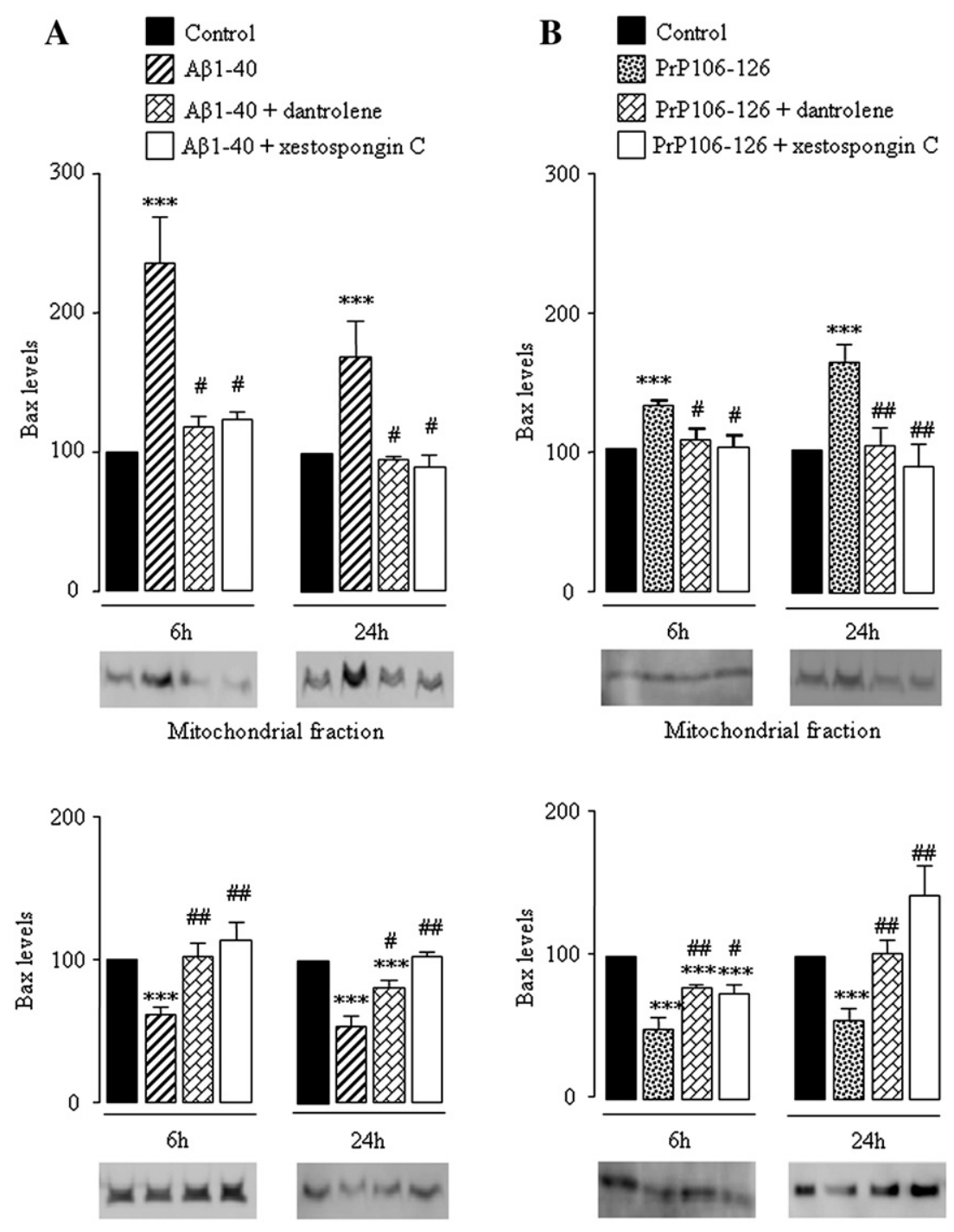

Cytosolic fraction

Cytosolic fraction

Fig. 5. A $\beta 1-40$ and PrP106-126 induce Bax translocation to mitochondria. Involvement of ER $\mathrm{Ca}^{2+}$ released through $\mathrm{IP}_{3} \mathrm{R}$ and $\mathrm{RyR}$. Cortical neurons were treated with $\mathrm{A} \beta 1-40(0.5 \mu \mathrm{M})(\mathrm{A})$ or PrP106-126 $(25 \mu \mathrm{M})(\mathrm{B})$, for 6 or $24 \mathrm{~h}$, in the absence or in the presence of dantrolene $(10 \mu \mathrm{M})$ or xestospongin $\mathrm{C}(1 \mu \mathrm{M})$. Bax levels in cytosolic- and mitochondria-enriched fractions were detected as a 20-kDa band by Western blot analysis, using a specific monoclonal antibody. To determine the significance of the differences in expression levels, data from at least three different experiments were analyzed by densitometry (graphs). Data were expressed as the mean \pm SEM. ${ }^{* * *} p<0.001$ with respect to control values. ${ }^{\#} p<0.05 ;{ }^{\# \#}<0.01$ with respect to $\mathrm{A} \beta$ or $\operatorname{PrP}$ addition. 

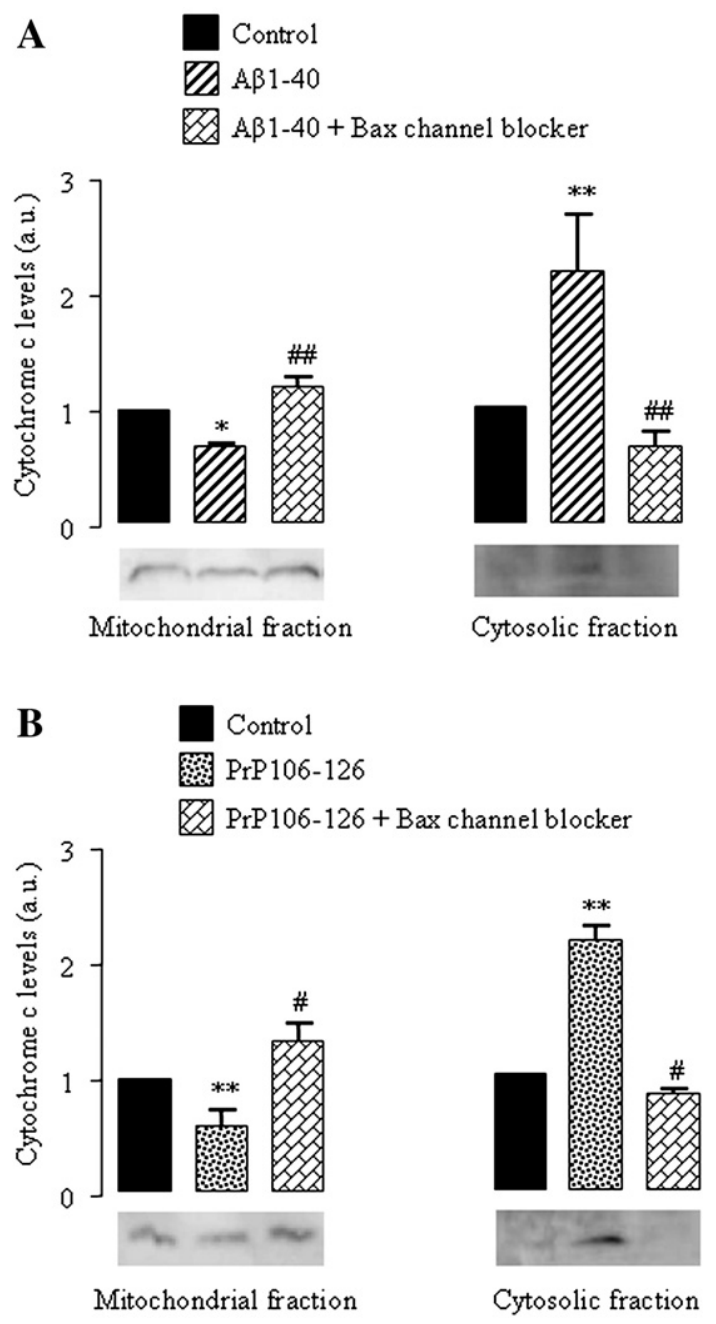

Fig. 6. Bax channel blocker prevents cytochrome $c$ release induced by A $\beta 1-$ 40 and PrP106-126. Cortical neurons were treated for $6 \mathrm{~h}$ with $5 \mu \mathrm{M} \mathrm{A} \beta 1-$ 40 , in the absence or in the presence of $50 \mathrm{nM}$ of Bax channel blocker (A) or with $25 \mu \mathrm{M}$ PrP106-126, in the absence or in the presence of $25 \mathrm{nM}$ of Bax channel blocker (B). Cytochrome $c$ levels in mitochondria- and cytosolicenriched fractions were detected as a 15-kDa band by Western blot analysis. Graphs represent the differences in expression levels from at least three different experiments, analyzed by densitometry. Data were expressed as the mean \pm SEM. ${ }^{*} p<0.05 ;{ }^{* *} p<0.01$ with respect to control values. ${ }^{*} p<0.05$; ${ }^{\# \#} p<0.01$ with respect to $\mathrm{A} \beta$ or $\operatorname{PrP}$ addition.

with $A \beta$ or PrP peptides in the presence of dantrolene $(10 \mu \mathrm{M})$ or xestospongin $\mathrm{C}(10 \mu \mathrm{M})$, GSH levels were similar to those observed in the control, demonstrating that RyR- and $\mathrm{IP}_{3} \mathrm{R}$-mediated $\mathrm{ER} \mathrm{Ca}^{2+}$ release is involved in GSH depletion triggered by $\mathrm{A} \beta$ and PrP peptides in cortical neurons (Figs. 4A and B). Dantrolene or xestospongin $\mathrm{C}$ per se did not affect GSH levels (Figs. 4A and B).

AB1-40 and PrP106-126 induce cytochrome c release due to the translocation of Bax to the mitochondria

High intramitochondrial $\mathrm{Ca}^{2+}$ and ROS can both contribute to the opening of the mitochondrial permeable transition pore (PTP) (Kroemer et al., 1998). Bax, a cytosolic Bcl-2 family protein, can translocate to mitochondria wherein it oligomerizes and inserts into the outer mitochondrial membrane, causing permeabilization and release of apoptogenic factors from the intermembrane space (Breckenridge and Xue, 2004). Both processes can contribute to the loss of $\Delta \psi_{\text {mit. }}$. We previously showed that both $\mathrm{A} \beta$ and $\operatorname{PrP}$ peptides induce the release of cytochrome $c$ in cortical neurons both at 6 and $24 \mathrm{~h}$ (Ferreiro et al., 2006) and so we hypothesized that these peptides could induce the translocation of Bax to the mitochondria by a mechanism involving the release of $\mathrm{Ca}^{2+}$ from ER. To investigate this possibility, we isolated mitochondrial and cytosolic fractions from untreated or A $\beta$ - or PrP-treated neurons and analyzed Bax levels by Western blotting. Furthemore, we also analysed the contribution of $\mathrm{ER} \mathrm{Ca}^{2+}$ release by pre-incubating cells with dantrolene or xestospongin C. Both A $\beta 1-40(0.5 \mu \mathrm{M})$ and PrP106$126(25 \mu \mathrm{M})$ increased Bax levels in the mitochondrial fraction at 6 and $24 \mathrm{~h}$ of incubation (Figs. 5A and B) and concomitantly decreased Bax levels in the cytosolic fraction (Figs. 5C and D). In addition, both dantrolene and xestospongin $\mathrm{C}$ prevented the translocation of Bax to the mitochondria in treated cells (Fig. 5). These results further implicate ER $\mathrm{Ca}^{2+}$, released through $\mathrm{IP}_{3} \mathrm{R}$ and RyR, in the mitochondrial dysfunction induced by $\mathrm{A} \beta$ and PrP peptides.
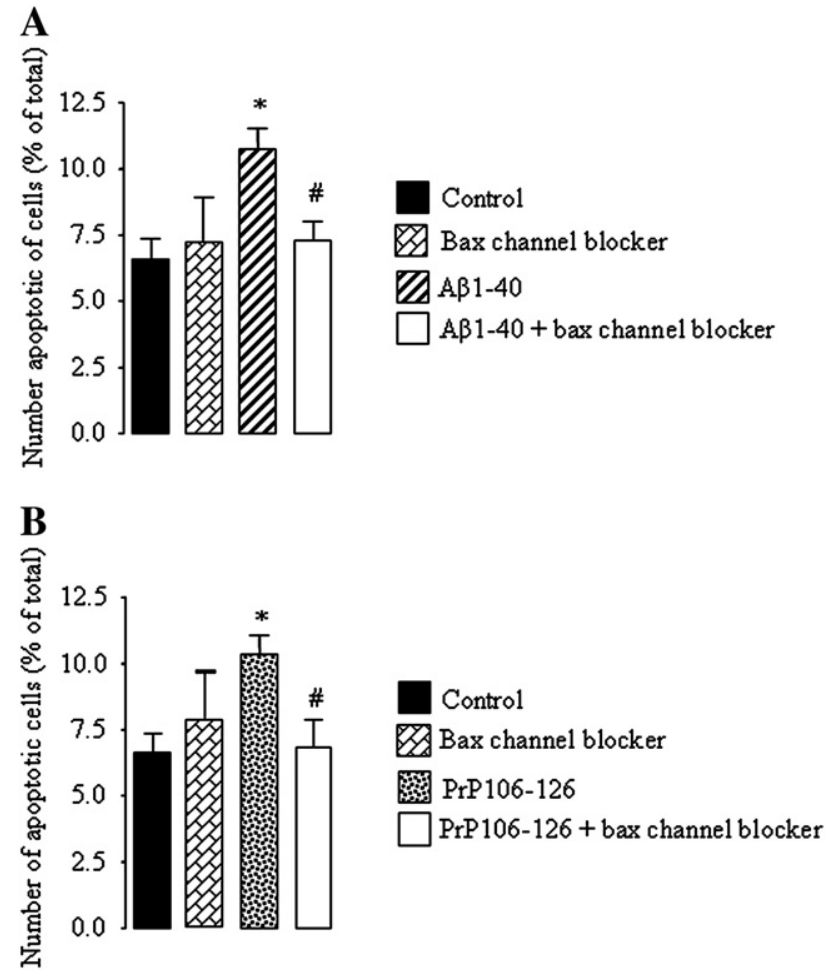

Fig. 7. Bax channel blocker reduces DNA fragmentation induced by A $\beta 1-$ 40 and PrP106-126. The number of cells exhibiting fragmented DNA was measured by fluorescence microscopy using SYTO-13 and PI staining in cortical neuronal cultures treated for $24 \mathrm{~h}$ with $0.5 \mu \mathrm{M} \mathrm{A} \beta 1-40$, in the absence or in the presence of $50 \mathrm{nM}$ of Bax channel blocker (A) or with $25 \mu \mathrm{M} \operatorname{PrP} 106-126$, in the absence or in the presence of $25 \mathrm{nM}$ of Bax channel blocker (B), as described in the Materials and methods section. The results, expressed as the percentage of the total number of cells, are the means \pm SEM of values corresponding at least to 3 experiments, each value being the mean of duplicate assays. ${ }^{*} p<0.05$ with respect to control values. ${ }_{p} p<0.05$ with respect to $\mathrm{A} \beta$ or $\operatorname{PrP}$ addition. 
To ascertain that cytochrome $c$ is released through the Bax channel formed in the outer mitochondrial membrane, the levels of this apoptogenic factor was analysed by Western blotting in mitochondrial and cytosolic fractions isolated from $\mathrm{A} \beta$ - or PrPtreated cortical neurons in the presence of a Bax channel blocker (Bombrun et al., 2003). In cells treated for $6 \mathrm{~h}$ with A $\beta 1-40(0.5 \mu \mathrm{M})$ or PrP106-126 (25 $\mu \mathrm{M})$, cytochrome $c$ levels decreased in the mitochondria, increasing the cytosolic content. This effect was prevented by the Bax channel blocker (Figs. 6A and B), implicating this channel in the release of cytochrome $c$ from mitochondria upon $\mathrm{A} \beta$ or PrP treatment (Figs. $6 \mathrm{~A}$ and $\mathrm{B}$ ). Similar results were obtained in cells treated with PrP106-126 and A $\beta 1-40$, in the presence or absence of Bax channel blocker for $24 \mathrm{~h}$ (data not shown).

To further analyse if Bax translocation to mitochondria was essential for $\mathrm{A} \beta$ - and PrP- induced apoptosis, cells were incubated with the Bax channel blocker and the number of apoptotic cells

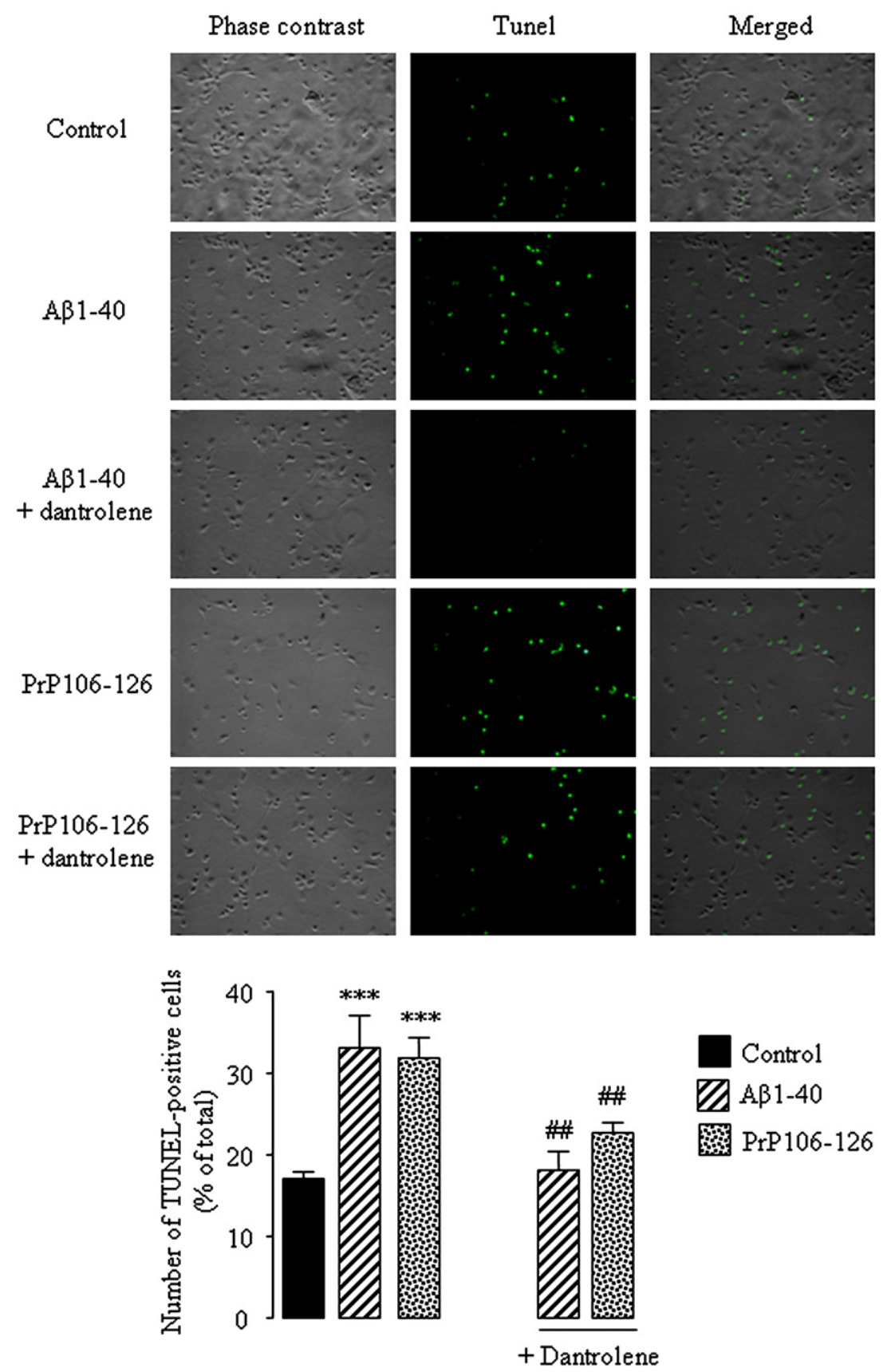

Fig. 8. A $1-40$ and PrP106-126 induce an increase in the number of TUNEL-positive cells. Protection by dantrolene. Cortical neurons were treated for $24 \mathrm{~h}$ with A $\beta 1-40(0.5 \mu \mathrm{M})$ or PrP106-126 $(25 \mu \mathrm{M})$, in the absence or in the presence of dantrolene $(10 \mu \mathrm{M})$ and TUNEL assay was performed as described in the Materials and methods section. Representative phase contrast, fluorescent (TUNEL-positive cells are green fluorescent) and merged images (400× magnification) are presented. (Graph) The numbers of TUNEL-positive cells are expressed as the percentage of the total number of cells and are the means \pm SEM of values corresponding at least to 3 experiments. ${ }^{* * *} p<0.001$ with respect to control values. ${ }^{\#} p<0.01$ with respect to $\mathrm{A} \beta$ or $\operatorname{PrP}$ addition. 
was quantified by fluorescence microscopy after SYTO-13/PI labelling. After $24 \mathrm{~h}$ of incubation with $\mathrm{A} \beta 1-40(0.5 \mu \mathrm{M})$ or PrP106-126 $(25 \mu \mathrm{M})$, the number of apoptotic cells significantly increased when compared to control values (Figs. 7A and B). In both cases, the Bax channel blocker reduced the number of apoptotic cells to values similar to the control (Fig. 7). In the case of PrP peptide, $25 \mathrm{nM}$ of Bax channel blocker effectively reduced the number of apoptotic cells (Fig. 7B), whereas $50 \mathrm{nM}$ were required to observe a similar effect against $A \beta$-induced cell death (Fig. 7A). Both concentrations of Bax channel blocker did not show any toxic effects per se (Figs. 7A and B).

\section{$A \beta$ - and PrP-induced apoptosis is dependent on $\mathrm{ER} \mathrm{Ca}^{2+}$ release}

Finally, to confirm the importance of ER $\mathrm{Ca}^{2+}$ release in the neuronal death induced by $\mathrm{A} \beta$ and PrP peptides, cortical cells were pre-incubated with dantrolene, which prevents the release of $\mathrm{Ca}^{2+}$ from the ER through RyR. Thereafter, apoptotic death was examined by the TUNEL assay. A $\beta 1-40(0.5 \mu \mathrm{M})$ and PrP106$126(25 \mu \mathrm{M})$ induced a 2-fold increase in the number of TUNELpositive cells, which was prevented by dantrolene (Fig. 8). These results further support the involvement of $\mathrm{ER} \mathrm{Ca}^{2+}$ release in the neuronal death that occurs upon $\mathrm{A} \beta$ and $\mathrm{PrP}$ treatment.

\section{Discussion}

Our results demonstrate that, in cortical neurons, $A \beta 1-40$ and PrP106-126 peptides activate the mitochondria-mediated apoptotic pathway, by a mechanism involving the release of $\mathrm{Ca}^{2+}$ from endoplasmic reticulum (ER) through channels associated with ryanodine receptors (RyR) and inositol 1,4,5-trisphosphate receptors $\left(\mathrm{IP}_{3} \mathrm{R}\right)$. The addition of $\mathrm{A} \beta 1-40(0.5 \mu \mathrm{M})$ or PrP106-126 $(25 \mu \mathrm{M})$ to cortical neuronal cultures depleted $\mathrm{ER} \mathrm{Ca}^{2+}$ stores, leading to the increase of cytosolic $\mathrm{Ca}^{2+}$ levels. Moreover, mitochondrial function was impaired by these peptides, which induced a significant reduction in mitochondrial membrane potential $\left(\Delta \psi_{\text {mit }}\right)$. This effect was significantly attenuated by inhibitors of $\mathrm{Ca}^{2+}$ release through channels associated to RyR and $\mathrm{IP}_{3} \mathrm{R}$, implicating $\mathrm{ER} \mathrm{Ca}^{2+}$ release in $\mathrm{A} \beta$ - and PrP-induced $\Delta \psi_{\text {mit }}$ loss. Furthermore, $\mathrm{A} \beta$ and $\operatorname{PrP}$ altered Bax localization, increasing the levels of this pro-apoptotic protein in the mitochondria. Bax channel formation was also shown to be essential for A $\beta$ - and PrP-induced cytochrome $c$ release and cell death. Finally, we provide evidence that clearly implicates the generation of reactive oxygen species (ROS) in mitochondrial dysfunction triggered by A $\beta 1-$ 40 and PrP106-126, which also decreased the endogenous antioxidant protection by lowering the levels of reduced glutathione (GSH).

Accumulation of unfolded proteins due to the perturbation of ER $\mathrm{Ca}^{2+}$ homeostasis can activate the unfolded protein response (UPR) and, consequently, the ER stress-induced apoptosis pathway (Kaufman, 1999; Pashen, 2001). UPR and ER stress have been shown to occur both in $\mathrm{AD}$ and $\mathrm{PrD}$ and to be involved in the neuronal death that occurs in both diseases (Hoozemans et al., 2005; Hetz et al., 2003). ER is the major $\mathrm{Ca}^{2+}$ storage organelle in the cell that can be released by both electrical and chemical cell stimulation (Bootman and Lipp, 2002; Berridge et al., 2000; Verkhratsky and Petersen, 2002), through two types of $\mathrm{Ca}^{2+}$ release channels, the $\mathrm{IP}_{3} \mathrm{R}$ and the RyR. $\mathrm{Ca}^{2+}$ is released from the $\mathrm{IP}_{3} \mathrm{R}$ in response to agonists of phospholipase $\mathrm{C}$ (PLC)-coupled receptors. Activation of PLC results in cleavage of $\operatorname{PtdIns}(4,5) \mathrm{P}_{2}$, leading to the liberation of diacylglycerol and $\operatorname{Ins}(1,4,5) \mathrm{P}_{3}\left(\mathrm{IP}_{3}\right)$ that binds to $\mathrm{IP}_{3} \mathrm{R}$ (Finch and Turner, 1991). $\mathrm{Ca}^{2+}$ released from $\mathrm{IP}_{3} \mathrm{R}$ further stimulates the release of $\mathrm{Ca}^{2+}$ through $\mathrm{RyR}$, a process known as calcium-induced calcium release (CICR). It was previously shown that the presence of the AD-linked presenilin 1 (PS1) mutation potentiates $\mathrm{IP}_{3}$-evoked $\mathrm{Ca}^{2+}$ transients (Stutzmann et al., 2004). More recently, RyR activation triggered by $\mathrm{Ca}^{2+}$ released from $\mathrm{IP}_{3} \mathrm{R}$ was demonstrated to be responsible for the exaggerated ER $\mathrm{Ca}^{2+}$ signals observed in the neurons of PS1 knock-in and 3xTg$\mathrm{AD}$ mice, further supporting the involvement of CICR through RyR in AD pathology (Stutzmann et al., 2006).

Perturbation in $\mathrm{Ca}^{2+}$ homeostasis, possibly through the early formation of membranar $\mathrm{A} \beta$ or $\operatorname{PrP~Ca}{ }^{2+}$ channels, may represent an initiating mechanism during $A \beta$ and $\operatorname{PrP}$ toxicity that can be extended to the ER as a death message (Bhathia et al., 2000; Simakova and Arispe, 2006; Lin et al., 1997). Further intracellular $\mathrm{Ca}^{2+}$ overload, due, in particular, to its release from the ER, can lead to the excessive $\mathrm{Ca}^{2+}$ uptake into mitochondria. This effect can be related to the close physical proximity between the ER and mitochondria (Rizzuto et al., 1998; Csordas et al., 1999). The massive $\mathrm{Ca}^{2+}$ influx into mitochondria collapse mitochondrial membrane potential $\Delta \psi_{\text {mit }}$, leading to cell death (Duchen, 2000; Hajnóczky et al., 2000). We report here, that A $\beta 1-40, \operatorname{PrP} 106-126$ and thapsigargin, an inhibitor of endoplasmic SERCA $\mathrm{Ca}^{2+}$-ATPase and known ER stressor, induce $\Delta \psi_{\text {mit }}$ loss involving the release of ER $\mathrm{Ca}^{2+}$ through $\mathrm{IP}_{3} \mathrm{R}$ and RyR. In 2002, Boya et al. had already showed that the ER stress-inducing agents, tunicamycin, inhibitor of the N-linked glycosylation, brefeldin A, inhibitor of ER-Golgi transport, and thapsigargin, induce signs of mitochondrial membrane permeabilization and loss of $\Delta \psi_{\text {mit }}$. Reduced $\Delta \psi_{\text {mit }}$ can also result from the opening of the mitochondrial transition pore (PTP). High intramitochondrial $\mathrm{Ca}^{2+}$ levels and generation of reactive oxygen species (ROS) both contribute to PTP opening. Indeed, $\mathrm{Ca}^{2+}$ dependent mitochondrial permeability transition can be facilitated by ROS (reviewed in Orrenius et al., 2007). We have previously provided evidence that ROS accumulation is an early event during A 1 1-40- and PrP106-126-induced apoptosis (Ferreiro et al., 2006). Herein, we showed that A $\beta 1-40-$, PrP106-126- and thapsigargininduced loss of $\Delta \psi_{\text {mit }}$, could be rescued by the antioxidants coenzyme Q10 (CoQ10) and vitamin E at concentrations that effectively disable ROS formation, implicating ROS in the reduced $\Delta \psi_{\text {mit }}$. The increment in ROS levels observed upon treatment with thapsigargin indicates that ER stress alters the equilibrium between ROS formation and the defence mechanisms of the cell. In fact, thapsigargin was previously shown to reduce GSH levels (Romero et al., 1997), which constitutes the first-line defence in the cellular antioxidant system. A $\beta 1-40$ and PrP106-126 also induced the depletion of GSH content that was prevented when $\mathrm{ER} \mathrm{Ca}^{2+}$ released through $\mathrm{IP}_{3} \mathrm{R}$ and RyR was inhibited.

Several proteins of the Bcl-2 family differentially affect mitochondrial function. One of these proteins is the pro-apoptotic protein Bax. In the presence of an pro-apoptotic stimuli, Bax translocates from the cytosol to the mitochondria, where it oligomerizes and forms a channel, leading to the permeabilization of the outer mitochondrial membrane, and to the release of cytochrome $c$ (Wei et al., 2000; Cheng et al., 2001). A $\beta 1-40$ and PrP106-126 induced the translocation of Bax to the mitochondria, which was prevented by dantrolene and xestospongin $\mathrm{C}$, demonstrating that $\mathrm{ER} \mathrm{Ca}^{2+}$ release through $\mathrm{IP}_{3} \mathrm{R}$ and RyR is involved in this process. We have previously shown that A $\beta 1-40$ and $\mathrm{PrP} 106-$ 126 induce cytochrome $c$ release from mitochondria in cortical neurons (Ferreiro et al., 2006) and now we demonstrate that the mitochondrial channels formed by Bax are implicated in the release 
of cytochrome $c$ and also in the apoptotic cell death that occur upon $\mathrm{A} \beta$ or $\operatorname{PrP}$ treatment. Moreover, we have recently shown that overexpression of the anti-apoptotic $\mathrm{Bcl}-2$ protein protects against $A \beta$ and PrP toxicity (Ferreiro et al., 2007), further implicating Bcl-2 family proteins in apoptosis induced by these amyloidogenic peptides. Previous reports have shown that ER stress-induced cell death requires the permeabilization of the mitochondrial membrane and that mouse embryonic fibroblasts lacking the pro-apoptotic proteins Bax and Bak become resistant to apoptosis induced by tunicamycin and brefeldin A (Boya et al., 2002). In addition, Bax and Bak were found to oligomerize in the ER membrane, resulting in ER $\mathrm{Ca}^{2+}$ depletion, processing of the ER-resident caspase-12 and cell death (Zong et al., 2003). Interestingly, GSH depletion enhances Bax translocation to the mitochondrial membrane, suggesting that changes in the redox status may be determinant for Bax-mediated cell death (Honda et al., 2004).

Once released from mitochondria, cytochrome $c$ binds to the apoptosis-inducing factor, mediating caspase- 9 activation, which in turns activates caspase-3 and subsequently promotes apoptosis (Desagher and Martinou, 2000). Our previous work demonstrated that $\mathrm{A} \beta$ and $\operatorname{PrP}$ peptides release cytochrome $c$ from mitochondria, activating caspase- 9 and -3 . Cytochrome $c$ was also found to bind $\mathrm{IP}_{3} \mathrm{R}$ adjacent to the mitochondria, sensitizing $\mathrm{IP}_{3} \mathrm{R}$ to increased $\mathrm{Ca}^{2+}$ release, potentiating mitochondrial and cytosolic $\mathrm{Ca}^{2+}$ overload and further cytochrome $c$ release (Boehning et al., 2003). This mechanism could also be operating under the conditions tested in the work here presented.

The notion that mitochondrial dysfunction is triggered by the ADand $\operatorname{PrD}$-associated $\mathrm{A} \beta$ and $\operatorname{PrP}$ peptides was supported by data obtained in our laboratory and by others. $A \beta$ was shown to decrease the activity of several enzymatic complexes of mitochondrial respiratory chain (Pereira et al., 1999). More recently, A $\beta$ was demonstrated to accumulate within mitochondria and such accumulation was shown to be associated to mitochondrial dysfunction (Caspersen et al., 2005; Reddy, 2006). A $\beta$ can also interact with A $\beta$ binding alcohol dehydrogenase (ABAD) in the mitochondria and this interaction promotes leakage of ROS, mitochondrial dysfunction and cell death (Lustbader et al., 2004). Moreover, the accumulation of full-length amyloid precursor protein (APP) was demonstrated to cause mitochondrial dysfunction and impaired energy metabolism (Anandatheerthavarada et al., 2003). Finally, functional mitochondria were previously shown to be required for $A \beta$ toxicity (Cardoso et al., 2001), revealing that mitochondria plays a fundamental role in the cell death that occurs in AD. In mitochondria of scrapie $\left(\operatorname{PrP}^{\mathrm{Sc}}\right)$ infected mice was reported the decrease of $\Delta \psi_{\text {mit }}$ and energy metabolites (ATP/ADP ratio) (Lee et al., 2000). The toxic sequence of $\mathrm{PrP}^{\mathrm{Sc}}$, PrP106-126, has also been previously shown to induce apoptosis through rapid depolarization of mitochondrial membranes, with subsequent cytochrome $c$ release and caspases activation (Forloni et al., 1993; O'Donavan et al., 2001; Agostinho and Oliveira, 2003). Recent results by our group obtained in mitochondrial DNA-depleted cells also demonstrate that functional mitochondria are required for ER stress-mediated cell death induced by $\mathrm{A} \beta$ and PrP peptides (Ferreiro et al., 2008 and unpublished data). The mechanism that is behind $\mathrm{A} \beta$ and PrP toxicity is not fully elucidated. The results of the present study, together with our own previously published results and that of others suggest a possible pathway. It can be hypothesized that $A \beta$ and PrP peptides induce the release of ER $\mathrm{Ca}^{2+}$ through $\mathrm{IP}_{3} \mathrm{R}$ and RyR, leading to the perturbation of $\mathrm{ER} \mathrm{Ca}^{2+}$ homeostasis and subsequently to ER stress. As a consequence of ER $\mathrm{Ca}^{2+}$ depletion, cytosolic $\mathrm{Ca}^{2+}$ levels are enhanced, ROS accumulate and Bax translocates to mitochondria. These events can cooperate to affect mitochondrial function, leading to cell death. Due to the close proximity between ER and mitochondria, $\mathrm{Ca}^{2+}$ can enter mitochondria and compromise the normal functioning of this organelle. ROS accumulation as a consequence of GSH depletion can further affect mitochondrial function leading to $\Delta \psi_{\text {mit }}$ loss. Bax translocates to mitochondria and induces cytochrome $c$ release, leading to the activation of caspase- 9 and -3 and finally cell death.

In conclusion, the results of our study provide evidence that a close relationship between the ER and the mitochondria occurs during $\mathrm{A} \beta$ - and PrP-induced cell death. We propose that compounds that regulate $\mathrm{Ca}^{2+}$ homeostasis, by inhibiting its release from ER, combined with antioxidants, could be therapeutical tools to fight the neuronal death that occurs in $\mathrm{AD}$ and $\mathrm{PrD}$.

\section{Acknowledgments}

This work was supported by FCT (Portuguese Research Council), project $\mathrm{n}^{\circ} \mathrm{POCTI} / 36101 / \mathrm{NSE} / 2000$. Elisabete Ferreiro has a $\mathrm{PhD}$ fellowship from FCT (SFRH/BD/14108/2003).

\section{References}

Agostinho, P., Oliveira, C.R., 2003. Involvement of calcineurin in the neurotoxic effects induced by amyloid-beta and prion peptides. Eur $\mathrm{J}$ Neurosci 17, 1-8.

Anandatheerthavarada, H.K., Biswas, G., Robin, M.A., Avadhani, N.G., 2003. Mitochondrial targeting and a novel transmembrane arrest of Alzheimer's amyloid precursor protein impairs mitochondrial function in neuronal cells. J Cell Biol 161, 41-54.

Baumann, O., Walz, B., 2001. Endoplasmic reticulum of animal cells and its organization into structural and functional domains. Int Rev Cytol 205, 149-214.

Bass, D.A., Parce, J.W., Dechatelet, L.R., Szejda, P., Seeds, M.C., Thomas, M., 1983. Flow cytometric studies of oxidative product formation by neutrophils: a graded response to membrane stimulation. J Immunol 130, 1910-1917.

Berridge, M.J., Lipp, P., Bootman, M.D., 2000. The versatility and universality of calcium signaling. Nature Rev. Mol Cell Biol 1, 11-21.

Bhathia, R., Lin, H., Lal, R., 2000. Fresh and globular amyloid beta protein (1-42) induces rapid cellular degeneration: evidence for AbetaP channel-mediated cellular toxicity. FASEB J. 14, 1233-1243.

Boehning, D., Patterson, R.L., Sedaghat, L., Glebova, N.O., Kurosaki, T., Snyder, S.H., 2003. Cytochrome $c$ binds to inositol $(1,4,5)$ trisphosphate receptors, amplifying calcium-dependent apoptosis. Nat Cell Biol 5, 1051-1061.

Bombrun, A., Gerber, P., Casi, G., Terradillos, O., Antonsson, B., Halazy, S., 2003. 3,6-dibromocarbazole piperazine derivatives of 2-propanol as first inhibitors of cytochrome $c$ release via Bax channel modulation. J Med Chem 46, 4365-4368.

Bootman, M.D., Lipp, P., 1999. Calcium signalling: ringing changes to the 'bell-shaped curve'. Curr Biol 9, R876-R878.

Boya, P., Cohen, I., Zamzami, N., Vieira, H.L., Kroemer, G., 2002. Endoplasmic reticulum stress-induced cell death requires mitochondrial membrane permeabilization. Cell Death Differ 9, 465-467.

Breckenridge, D.G., Xue, D., 2004. Regulation of mitochondrial membrane permeabilization by BCL-2 family proteins and caspases. Curr Opin Cell Biol 16, 647-652.

Cardoso, S.M., Santos, S., Swerdlow, R.H., Oliveira, C.R., 2001. Functional mitochondria are required for amyloid beta-mediated neurotoxicity. FASEB J 15, 1439-1441.

Caspersen, C., Wang, N., Yao, J., Sosunov, A., Chen, X., Lustbader, J.W., Xu, H.W., Stern, D., McKhann, G., Yan, S.D., 2005. Mitochondrial Abeta: a potential focal point for neuronal metabolic dysfunction in Alzheimer's disease. FASEB J 19, 2040-2041. 
Cheng, E.H., Wei, M.C., Weiler, S., Flavell, R.A., Mak, T.W., Lindsten, T., Korsmeyer, S.J., 2001. BCL-2, BCL-X(L) sequester BH3 domain-only molecules preventing BAX- and BAK-mediated mitochondrial apoptosis. Mol Cell 8, 705-711.

Csordas, G., Thomas, A.P., Hajnoczky, G., 1999. Quasi-synaptic calcium signal transmission between endoplasmic reticulum and mitochondria. EMBO J 18, 96-108.

Desagher, S., Martinou, J.C., 2000. Mitochondria as the central control point of apoptosis. Trends Cell Biol 10, 369-377.

Duchen, M.R., 2000. Mitochondria and calcium: from cell signalling to cell death. J. Physiol. 529 (Pt 1), 57-68.

Ferreiro, E., Oliveira, C.R., Pereira, C., 2004. Involvement of endoplasmic reticulum $\mathrm{Ca}^{2+}$ release through ryanodine and inositol 1,4,5-triphosphate receptors in the neurotoxic effects induced by the amyloid-b peptide. J Neurosci Res 76, 872-880.

Ferreiro, E., Resende, R., Costa, R., Oliveira, C.R., Pereira, C.M., 2006. An endoplasmic-reticulum-specific apoptotic pathway is involved in prion and amyloid-beta peptides neurotoxicity. Neurobiol Dis 23, 669-678.

Ferreiro, E., Eufrásio, A., Pereira, C., Oliveira, C.R., Rego, A.C., 2007. Bcl2 overexpression protects against amyloid-Beta and prion toxicity in GT1-7 neural cells. J Alzheimers Dis 12, 223-228.

Ferreiro, E., Costa, R., Marques, S., Cardoso, S.M., Oliveira, C.R., Pereira, C.M., 2008. Involvement of mitochondria in endoplasmic reticulum stress-induced apoptotic cell death pathway triggered by the prion peptide $\operatorname{PrP}(106-126)$. J Neurochem 104, 766-776.

Ferri, K., Kroemer, G., 2000. Organelle-specific initiation of cell death pathway. Nat. Cell Biol. 3, E255-E263.

Finch, E.A., Turner, T.J., Goldin, S.M, 1991. Calcium as a coagonist of inositol 1,4,5-trisphosphate-induced calcium release. Science 252, 443-446.

Forloni, G., Angeretti, N., Chiesa, R., Monzani, E., Salmona, M., Bugiani, O., Tagliavini, F., 1993. Neurotoxicity of a prion protein fragment. Nature 362, 543-546.

Hajnóczky, G., Csordas, G., Madesh, M., Pacher, P., 2000. Control of apoptosis by IP(3) and ryanodine receptor driven calcium signals. Cell Calcium 28, 349-363.

Hetz, C., Russelakis-Carneiro, M., Maundrell, K., Castilla, J., Soto, C., 2003. Caspase-12 and endoplasmic reticulum stress mediate neurotoxicity of pathological prion protein. EMBO J 22, 5435-5445.

Hetz, C., Russelakis-Carneiro, M., Walchli, S., Carboni, S., Vial-Knecht, E., Maundrell, K., Castilla, J., Soto, C., 2005. The disulfide isomerase Grp58 is a protective factor against prion neurotoxicity. J Neurosci 25 , 2793-2802.

Hertz, E., Yu, A.C.H., Hertz, L., Juurlink, B.H.J., Schousboe, A., 1989. Preparation of primary cultures of mouse cortical neurons. In: Shahar, A., De Vellis, J., Vernadakis, A., Haber, V. (Eds.), A Dissection and Tissue Culture Manual of the Nervous System. Alan R. Liss, New York.

Honda, T., Coppola, S., Ghibelli, L., Cho, S.H., Kagawa, S., Spurgers, K.B., Brisbay, S.M., Roth, J.A., Meyn, R.E., Fang, B., McDonnell, T.J., 2004. GSH depletion enhances adenoviral bax-induced apoptosis in lung cancer cells. Cancer Gene Ther 11, 249-255.

Hoozemans, J.J.M., Veerhuis, R., Van Haastert, E.S., Rozemuller, J.M., Baas, F., Eikelenboom, P., Scheper, W., 2005. The unfolded protein response is activated in Alzheimer's disease. Acta Neuropathol 110, 165-172.

Kaufman, R.J., 1999. Stress signaling from the lumen of the endoplasmic reticulum: coordination of gene transcriptional and translational controls. Genes Dev 13, 1211-1233.

Katayama, T., Imaizumi, K., Sato, N., Miyoshi, K., Kudo, T., Hitomi, J., Morihara, T., Yoneda, T., Gomi, F., Mori, Y., Nakano, Y., Takeda, J., Tsuda, T., Itoyama, Y., Murayama, O., Takashima, A., St George-Hyslop, P., Takeda, M., Tohyama, M., 1999. Presenilin-1 mutations downregulate the signalling pathway of the unfolded-protein response. Nat Cell Biol. 1, 479-485.

Kluck, R.M., Bossy-Wetzel, E., Green, D.R., Newmeyer, D.D., 1997. The release of cytochrome $c$ from mitochondria: a primary site for Bcl-2 regulation of apoptosis. Science 275, 1132-1136.

Kroemer, G., Dallaporta, B., Resche-Rigon, M., 1998. The mitochondrial death/life regulator in apoptosis and necrosis. Annu Rev Physiol 60, 619-642.
Lee, M.S., Kwon, Y.T., Li, M., Peng, J., Friedlander, R.M., Tsai, L.H., 2000. Neurotoxicity induces cleavage of p35 to p 25 by calpain. Nature 405 , 360-364.

Li, F., Srinivasan, A., Wang, Y., Armstrong, R.C., Tomaselli, K.J., Fritz, L.C., 1997. Cell-specific induction of apoptosis by microinjection of cytochrome $c$. Bcl-xL has activity independent of cytochrome $c$ release. J Biol Chem 272, 30299-30305.

Lin, M.C., Mirzabekov, T., Kagan, B.L., 1997. Channel formation by a neurotoxic prion protein fragment. J Biol Chem 272, 44-47.

Liu, X., Kim, C.N., Yang, J., Jemmerson, R., Wang, X., 1996. Induction of apoptotic program in cell-free extracts: requirement for dATP and cytochrome $c$. Cell 86, 147-157.

Luetjens, C.M., Bui, N.T., Sengpiel, B., Munstermann, G., Poppe, M., Krohn, A.J., Bauerbach, E., Krieglstein, J., Prehn, J.H., 2000. Delayed mitochondrial dysfunction in excitotoxic neuron death: cytochrome $c$ release and a secondary increase in superoxide production. J Neurosci $20,5715-5723$.

Lustbader, J.W., Cirilli, M., Lin, C., Xu, H.W., Takuma, K., Wang, N., Caspersen, C., Chen, X., Pollak, S., Chaney, M., Trinchese, F., Liu, S., Gunn-Moore, F., Lue, L.F., Walker, D.G., Kuppusamy, P., Zewier, Z.L., Arancio, O., Stern, D., Yan, S.S., Wu, H., 2004. ABAD directly links Abeta to mitochondrial toxicity in Alzheimer's disease. Science 304, 448-451.

Macho, A., Hirsch, T., Marzo, I., Marchetti, P., Dallaporta, B., Susin, S.A., Zamzami, N., Kroemer, G., 1997. Glutathione depletion is an early and calcium elevation is a late event of thymocyte apoptosis. J Immunol 158, 4612-4619.

Moreira, P.I., Santos, M.S., Sena, C., Seica, R., Oliveira, C.R., 2005. Insulin protects against amyloid beta-peptide toxicity in brain mitochondria of diabetic rats. Neurobiol Dis 18, 628-637.

Nakagawa, T., Zhu, H., Morishima, N., Li, E., Xu, J., Yankner, B.A., Yuan, J., 2000. Caspase-12 mediates endoplasmic-reticulum-specific apoptosis and cytotoxicity by amyloid- $\beta$. Nature $403,98-103$.

Nutt, L.K., Chandra, J., Pataer, A., Fang, B., Roth, J.A., Swisher, S.G., O’Neil, R.G., McConkey, D.J., 2002. Bax-mediated $\mathrm{Ca}^{2+}$ mobilization promotes cytochrome $c$ release during apoptosis. J Biol Chem 277, 20301-20308.

O'Donavan, C.N., Tobin, D., Cotter, T.G., 2001. Prion protein fragment PrP(106-126) induces apoptosis via mitochondrial disruption in human neuronal SH-SY5Y cells. J Biol Chem 276, 43516-43523.

Orrenius, S., Gogvadze, V., Zhivotovsky, B., 2007. Mitochondrial oxidative stress: implications for cell death. Annu. Rev. Pharmacol. Toxicol. 47, $143-183$.

Oyadomari, S., Araki, E., Mori, M., 2002. Endoplasmic reticulum stressmediated apoptosis in pancreatic beta-cells. Apoptosis 7, 335-345.

Palmeira, C.M., Moreno, A.J.M., Madeira, V.M.C., Wallace, K.B., 1996. Continuous monitoring of mitochondrial membrane potential in hepatocyte cell suspensions. J. Pharmacol. Toxicol. Methods 35, 35-43.

Pashen, W., 2001. Dependence of vital cell function on endoplasmic reticulum calcium levels: implications for the mechanisms underlying neuronal cell injury in different pathological states. Cell Calcium 29, 1-11.

Pereira, C., Santos, M.S., Oliveira, C.R., 1999. Involvement of oxidative stress on the impairment of energy metabolism induced by Ab peptides on PC12 cells: protection by antioxidants. Neurobiol Dis 6, 209-219.

Prusiner, S.B., 1996. Molecular biology and pathogenesis of prion diseases. Trends Biochem Sci 252, 482-487.

Reddy, P.H., 2006. Amyloid precursor protein-mediated free radicals and oxidative damage: implications for the development and progression of Alzheimer's disease. J Neurochem 96, 1-13.

Rizzuto, R., Pinton, P., Carrington, W., Fay, F.S., Fogarty, K.E., Lifshitz, L.M., Tuft, R.A., Pozzan, T., 1998. Close contacts with the endoplasmic reticulum as determinants of mitochondrial $\mathrm{Ca}^{2+}$ responses. Science 280, 1763-1766.

Romero, D.L., Mounho, B.J., Lauer, F.T., Born, J.L., Burchiel, S.W., 1997. Depletion of glutathione by benzo(a)pyrene metabolites, ionomycin, thapsigargin, and phorbol myristate in human peripheral blood mononuclear cells. Toxicol Appl Pharmacol 144, 62-69.

Simakova, O., Arispe, N.J., 2006. Early and late cytotoxic effects of external application of the Alzheimer's Abeta result from the initial formation and function of Abeta ion channels. Biochemistry 45, 5907-5915. 
Stutzmann, G.E., Caccamo, A., LaFerla, F.M., Parker, I., 2004. Dysregulated IP3 signaling in cortical neurons of knock-in mice expressing an Alzheimer's-linked mutation in presenilin1 results in exaggerated $\mathrm{Ca}^{2+}$ signals and altered membrane excitability. J Neurosci 24, 508-513.

Stutzmann, G.E., Smith, I., Caccamo, A., Oddo, S., Laferla, F.M., Parker, I., 2006. Enhanced ryanodine receptor recruitment contributes to $\mathrm{Ca}^{2+}$ disruptions in young, adult, and aged Alzheimer's disease mice. J Neurosci 26, 5180-5189.

Verkhratsky, A., Petersen, O.H., 2002. The endoplasmic reticulum as an integrating signalling organelle: from neuronal signalling to neuronal death. Eur J Pharmacol 447, 141-154.

Wei, M.C., Lindsten, T., Mootha, V.K., Weiler, S., Gross, A., Ashiya, M., Thompson, C.B., Korsmeyer, S.J., 2000. tBID, a membrane-targeted death ligand, oligomerizes BAK to release cytochrome $c$. Genes Dev 14, 2060-2071.
Wei, M.C., Zong, W.X., Cheng, E.H., Lindsten, T., Panoutsakopoulou, V., Ross, A.J., Roth, K.A., MacGregor, G.R., Thompson, C.B., Korsmeyer, S.J., 2001. Proapoptotic BAX and BAK: a requisite gateway to mitochondrial dysfunction and death. Science 292, 727-730.

Wisniewski, T., Ghiso, J., Frangione, B., 1997. Biology of A beta amyloid in Alzheimer's disease. Neurobiol Aging 4, 313-328.

Yang, J., Liu, X., Bhalla, K., Kim, C.N., Ibrado, A.M., Cai, J., Peng, T.I., Jones, D.P., Wang, X., 1997. Prevention of apoptosis by Bcl-2: release of cytochrome $c$ from mitochondria blocked. Science 275, $1129-1132$.

Zong, W.X., Li, C., Hatzivassiliou, G., Lindsten, T., Yu, Q.C., Yuan, J., Thompson, C.B., 2003. Bax and Bak can localize to the endoplasmic reticulum to initiate apoptosis. J Cell Biol 162, 59-69.

Zoratti, M., Szabo, I., 1995. The mitochondrial permeability transition. Biochim Biophys Acta 1241, 139-176. 